\title{
A Study on Problems with Reform of Performance Salary Reform in Colleges and Universities and Countermeasures-A case study of Colleges
}

\author{
Lei Xia \\ Department of Accounting, Chongqing Business Vocational College, Chongqing, China
}

Keywords: Colleges and universities, performance salary, reform

\begin{abstract}
The reform of performance salary in colleges and universities is of great significance for strengthening the talent team construction of colleges and universities, improving the competitive advantage in colleges and universities, and implementing the strategy of reinvigorating China through human resource development. However, some colleges and universities have some problems with the performance salary reform, which has resulted in certain conflicts. This paper firstly introduces College S' performance salary reform program, and deeply analyzes the existing problems with the performance salary reform of College S. On this basis, the countermeasures are proposed to solve these problems.
\end{abstract}

\section{Introduction}

China has been implementing the reform of performance salary of public institutions in an all-round matter since 2010. As for the performance salary, the organizations have the right to set up the implementation measures and decide the distribution mode independently following specified procedures within the total amount of performance salary as approved by the superior overseeing authority. The distribution modes can be flexible and diversified. As such, the organizations are highly autonomous to this end. However, there are various problems with the process of performance salary reform, including repeated failure of the performance reform scheme to be approved by the Teacher's Representative Meeting, reduction of the teachers' income in colleges and universities as a result, and unfairness in performance assessment. All these have resulted in a number of internal conflicts, and have drawn extensive attention of the society. Therefore, it is very urgent to establish a fair, science-based and rational performance salary system. This paper will have an in-depth discussion about this topic.

\section{Introduction to performance salary reform of College S}

2.1 The guiding ideology for establishment of the performance salary reform scheme of College $\mathrm{S}$ follows the principle that "the salary depends on the position, the responsibility accords with the salary, the salary is distributed according to the work, higher salary is given to a better performer, efficiency is emphasized and fairness is highlighted". The teachers on the front line are favored in particular, so as to stimulate the enthusiasm of the faculty members about work and their creativity.

2.2 Composition of the performance salary items of College $\mathrm{S}$ and their composition proportions (See Table 1) 
Table 1 Composition of Performance Salary Items of College S and their Composition Proportions

\begin{tabular}{|c|c|c|}
\hline Composition & Item & $\begin{array}{l}\text { Proportion in } \\
\text { the } \\
\text { performance } \\
\text { salary }\end{array}$ \\
\hline Basic allowance & The basic performance salary (fixed) & \multirow{8}{*}{$70 \%$} \\
\hline \multirow{2}{*}{$\begin{array}{l}\text { Position } \\
\text { allowance }\end{array}$} & Class-hour allowance (full-time teachers) & \\
\hline & Position allowance (management and logistics) & \\
\hline \multirow{5}{*}{$\begin{array}{c}\text { Other } \\
\text { allowances }\end{array}$} & $\begin{array}{l}\text { Allowance for well-known teachers, back-bone teachers } \\
\text { and major leaders }\end{array}$ & \\
\hline & $\begin{array}{l}\text { Allowance for attachment, learning and training of } \\
\text { teachers }\end{array}$ & \\
\hline & $\begin{array}{l}\text { Topic assignment, paper review, examination monitoring, } \\
\text { guidance and defense allowance }\end{array}$ & \\
\hline & $\begin{array}{l}\text { Allowance for scientific research, teaching reform and } \\
\text { project of the subject }\end{array}$ & \\
\hline & Festival sympathy money and others & \\
\hline \multirow{2}{*}{$\begin{array}{l}\text { Assessment } \\
\text { allowance }\end{array}$} & $\begin{array}{l}\text { Teaching and quality performance assessment (full-time } \\
\text { teachers) }\end{array}$ & \multirow{2}{*}{$30 \%$} \\
\hline & $\begin{array}{l}\text { Work target responsibility assessment (management and } \\
\text { logistics) }\end{array}$ & \\
\hline
\end{tabular}

\subsection{Specific content}

2.3.1 The basic allowance is set up in accordance with the standards specified in Standard Theoretical Value of Performance Salary of City-level Public Institutions of XX City, and depends on the position rank and specified standard of the individual, and is subject to adjustment based on the superior policy and change of the individual rank. This part is fixed and an individual can get the basic allowance by only completing the minimum amount of work.

2.3.2 Position allowance: The full-time teacher position, management position and logistic position are given the position allowance. The position allowance for full-time teachers is actually the class-hour allowance. The unit class-hour allowance multiplying the number of class-hours equals the position allowance of a full-time teacher. The standard for unit class-hour allowance is determined based on the title. A higher title means a higher unit allowance standard. At the same time, the minimum and maximum amounts of work are specified for full-time teachers. For part-time teachers, the allowance should be $85 \%$ of the allowance for their title. The management position allowance and logistics position allowance are given to the non-leadership positions and leadership positions. For non-leadership positions, the allowance is issued based on the number of grades of the position. For leadership positions, the position standard will be followed.

2.3.3 Other allowances: The specific content of other allowance is shown in Table 1. The festival sympathy money included as other allowances is now generally not issued, being restricted by the national regulations. The remaining part is unsure.

\subsubsection{Assessment allowance}

Total amount of annual target assessment allowance $=$ Total amount of approved performance salary - $\sum$ Basic allowance - $\sum$ Position and class-hour allowances - $\sum$ Other allowances $-\sum$ Reserved amount of the superior level (3\% of the total performance allowance)

Total amount of annual individual target assessment allowance $=$ Total amount of annual target assessment allowance $-\sum$ Annual target assessment allowance of the department

The annual per capita assessment allowance standard = Total amount of annual individual target assessment allowance $\div$ Number of teaching and administrative staff members 
The actual annual assessment allowance for individual target assessment is obtained by multiplying the annual per capita assessment allowance standard with the assessment coefficient. The assessment coefficient is respectively 1.3, 1, 0.5 and 0 for excellence, competence, substantial competence and incompetence.

\section{Problems with reform of performance salary of College $S$}

The performance salary reform scheme of College S, to a certain extent, reflects the concept "performance. However, there are still the following problems:

i. The performance salary scheme fails to follow the guiding ideology of "performance". What is performance? What is the purpose of issuing performance salary? Performance is short for "achievement and effect", and it is the production of input and the gains obtained after paying the cost. The purpose of issuing performance salary is to break with the traditional equalitarianism and the round-robin income distribution system, and stimulate the teachers' enthusiasm about education, teaching and scientific research and their creativity, in an ultimate effort to ensure more pay for more work and higher salary for better workers. The survey of the performance salary reform scheme of College $\mathrm{S}$ and other universities and universities showed that the full-time teachers became less willing to give lectures after implementation of the performance salary scheme, and they would only want to complete the minimum amount of work. Though more class-hour allowance is given for more class hours, the class-hour allowance is quite low and the full-time teachers think their give is not proportional to their gains. This is why they are not motivated.

ii. The income of full-time teachers is quite low and the satisfaction degree of full-time teachers is also low. It is estimated that the annual income of a grade- 7 associate professor is only about 65,000 yuan, assuming the average work amount of a full-time teacher of College $S$, and that of a grade- 9 lecturer is only 50,000 yuan or so; that of a grade- 11 assistant lecturer is only about 40,000 yuan. According to the statistics released by the municipal statistical bureau, the annual average salary of employees of non-private organizations in 2016 was 65,545 yuan, and that of the employees of private organizations was 47,345 yuan. This means that the average salary of a university teacher was even lower than the average level. It can be inferred that the full-time teachers will not feel very good. At the same time, the salary of employees on the management positions is much higher than that of the full-time teachers of the same level. I would like to ask what the core work is for a school, which is supposed to impart knowledge and educate people. The dominant position of teachers seems to be nothing. Should teachers still stick to their ideas in such a circumstance? For different reasons, in many colleges and universities, the performance salary reform has resulted only in lower income of the teachers on the front line. The full-time teachers almost all voted against the performance salary scheme. However, this has been of no use and the performance salary scheme was still "passed” at the Teacher's Representative Meeting.

iii. The performance assessment mechanism is missing and there are a lot of uncertainties. Firstly, in the performance salary scheme of College $S$, it is only stated that the performance assessment is carried out at the year end, and the assessment allowance is related to the assessment results. However, it says nothing about the way of assessment and the specific assessment scheme. Secondly, performance allowance is only issued after deduction of the basic allowance, class-hour or position allowance and other allowances. The other allowances referred to in this paragraph are highly uncertain. Therefore, there will be very little left for the other allowances. The "assessment allowance", as the core of the performance salary, is rendered pointless as such.

iv. The group performance assessment is irrational. The annual assessment within the department is irrational to a certain extent. Firstly, a group refers only to an administrative department, and does not include other groups. Secondly, the annual assessment allowance of the department is distributed in the department as a whole, and some departments have only one or two employees and the other departments have thirty or even fourth employees, despite the same amount of 
allowance.

v. The existence of a huge number of teachers "assuming administrative as well as professional responsibilities" has resulted in an even wider income gap. Almost every college and university has teachers "assuming administrative as well as professional responsibilities". However, some colleges and universities have many, and almost all employees on the management positions hold professional and technical titles. This will result in bad consequences in two aspects. Firstly, those persons act as part-time teachers to teach students and gain class-hour allowance, thus obtaining double incomes. In particular, some schools have posed no limit on the number of class hours of part-time teachers. Secondly, the proportion of professional and technical titles is limited in each college and university. If the employees on the management positions hold such titles, the full-time teachers will be deprived of part of the quota of the title, which makes professional title acquisition even harder for full-time teachers.

\section{A study on countermeasures for performance salary reform in colleges and universities}

4.1 A complete and sound performance salary scheme should be designed. The design of performance salary should be improved from the following aspects:

4.1.1 In-depth survey is required before setup of the performance salary scheme. Firstly, survey of the commodity price level and salary level is required; secondly, survey of the performance salary scheme and problems with implementation of the performance salary of sister colleges and universities is needed, to learn successful experience and lessons. Thirdly, survey and analysis of income of teaching and administrative staff in the past 3 years are needed. Eventually, survey of opinions and suggestions of the teaching and administrative staff on reform of performance salary is required.

4.1.2 The guiding ideology and principle of performance salary reform should be made clear. The guiding ideology of performance salary is that "the salary is distributed according to the work, higher pay is given to those who do more work, and higher salary is given to a better performer", and that "efficiency comes first, and fairness is also important". This means that the benefit of the teaching and administrative staff members should be taken into consideration, and the characteristic "high human capital" of college and university teachers should be taken into consideration as well. The guiding ideology should be implemented to the fullest once determined, and should not only be empty talk. It should be ensured that all teaching and administrative staff members are benefited from implementation of such reform.

4.1.3 The entire process of scheme setup should be open and transparent. The performance salary is closely related to the vital interests of each teaching and administrative staff member and it should not be regarded as the work task of only the personnel department. As such, a performance salary reform group should be established before setting up the performance salary scheme. The group should be made up of representatives of leaders, non-leadership management, full-time teachers and logistics personnel, with reasonable proportions. The personnel department should work out a preliminary scheme after detailed survey, with the specific situation of the college or university taken into consideration. The preliminary scheme is then cascaded to the public by the representatives and the public should be given the opportunity to offer modification opinions, which should be discussed by the reform group. Afterwards, the personnel department should modify the scheme and another discussion is required. After several rounds, an agreement will be reached. The entire process is transparent and open without cover or haste.

4.2 A science-based and rational performance assessment should be set up and maintained. The biggest challenge encountered in the process of implementation of performance salary in colleges and universities is the incompleteness of the performance assessment mechanism. This is the main reason that the full-time teachers are against the performance salary scheme. There is significant 
uncertainty and ambiguity with respect to the part that accounts for $30 \%$ of the total performance salary amount. As such, establishment of a rational and science-based performance assessment mechanism is the key to smooth implementation of the performance salary reform. As such, a complete set of performance assessment and management system should be set up and maintained while implementing the performance salary. Firstly, different assessment systems should be set up for different positions, and for full-time teachers, "equal importance should be attached to teaching and scientific research, process and results, quantification and quality determination, and long term and short term". Secondly, the fairness, equality and objectiveness of the assessment results should be ensured. The teachers should be informed of the performance assessment results, and then they will understand their achievements and insufficiency. This way, teachers will be encouraged by their achievements and make improvement with respect to the insufficiency in the future. This is the very purpose of the performance assessment. Furthermore, in the annual department assessment as part of the performance salary assessment, the departments should not be "treated equally without discrimination". Full consideration should be given to size of the department, number of staff members and specific situation of each department when determining the amount of performance assessment allowance.

4.3 The group performance salary should be set up. The power of an individual is quite restrained, and the wisdom of a group should be highlighted. Therefore, besides the "administrative department", the teaching group and scientific research group should be built up, and the "group performance salary" system should be established to encourage teamwork, and create an atmosphere of union and cooperation in the school. For example, the teaching group may be excellent course group and professional course group, and they should be given supporting group performance salary after participating in related activities or finishing work tasks.

4.4 The problems with the persons "assuming administrative as well as professional responsibilities" should be treated properly. Persons "assuming administrative as well as professional responsibilities" have experience in both management and teaching and are making noticeable contribution to the education, teaching, management and scientific research of the school. However, if there are too many such persons, there will be bad consequences. Therefore, the author suggests that the number of persons "assuming administrative as well as professional responsibilities" be reduced. The persons on the teaching management positions are allowed to assume administrative as well as professional responsibilities. For example, the head of the teaching and research section and officials in charge of teaching may also assume the teaching responsibility. For other positions, no doubling is allowed unless special conditions are met. Furthermore, the work amount of part-time teachers should be restricted within a certain range.

4.5 The performance salary should be dynamic and lasted. Reform of performance salary can not be done in one day. In its implementation, there will surely be various problems. The university officials should listen to opinions of the teaching and administrative staff members, and attach importance to those problems and try to solve them. The performance salary, once determined, should not remain unchanged. It should change and improve with development of the school and the society. In addition, the long-term development of teaching and administrative staff members should be considered when determining the performance salary. For teachers as high level intellectuals, spiritual needs and self-development need are as important as the material needs. Therefore, creating a favorable teaching and scientific research atmosphere, providing various opportunities for training and further education, paying attention to mental and physical health of teaching and administrative staff members and caring the employees' families are also helpful to encouraging staff members.

\section{Conclusion}

A science-based, rational and fair performance salary distribution system is directly related to 
improvement of satisfaction and loyalty of teachers. The enthusiasm, creativity and initiative of teachers pose a direct impact on the future development of colleges and universities, and on the quality of higher education in China. As such, a cautious and serious attitude towards the work is the key to constant improvement and development of the performance salary reform.

\section{References}

[1] Zhang Cheng: A Discussion of Performance Salary Reform in Colleges and Universities [J] Human Resource Management, 2017, (03): 094 095;

[2] Wang Hongyuan: Path Selection for Performance Salary Reform in Colleges and Universities On Hot Issues in Reform [J] Education Accounting Research, 2016, (06): 007 008;

[3] Li Qian and Shi Wanbing: Dilemma in Reform of Performance Salary System for College and University Teachers and the Outlet - Analysis of Performance Salary Schemes of 21 Colleges and Universities [J] Education Accounting Research, 2016, (04): 41 45;

[4] Wang Lei: A Study on Problems with Implementation of Performance Salary Reform in Colleges and Universities of Guangdong ii - Analysis of Salary Problems of a University between 2012 and 2016 [J] Economic Management, 2017 (12): 19 21;

[5] Pan Zhongqin and Li Baisheng: A Discussion of Practical Problems with Implementation of Performance Salary in Colleges and Universities and Countermeasures [J] Intelligence, 2017 (16): 96;

[6] Wang Hongyuan: Path Selection of Performance Salary Reform in Colleges and Universities On Hot Issues in Reform [J] Finance and Tax, 2017 (02): 85 89;

[7] Wang Yin: A Study on Problems with Performance Salary Reform in Colleges and Universities Given the New Trend and Countermeasures [J] Human Resource Management, 2017 (08): 202 